\title{
Literature Review: Paparan Jangka Panjang PM2.5 Berisiko Meningkatkan Kematian Akibat COVID-19
}

\section{Literature Review: Long-term Exposure to PM2.5 is at Risk of Increasing Mortality Due to COVID-19}

Tri Meidya Rahmawati1 ${ }^{* 1}$, Ririh Yudhastuti ${ }^{1}$

\begin{abstract}
ABSTRAK
Latar Belakang: Jumlah kasus terhitung hingga 5 Mei 2021 terdapat 154.815 .600 kasus yang terkonfirmasi COVID-19, termasuk 3.236.104 kematian dari seluruh dunia. $\mathrm{PM}_{2.5}$ diduga sebagai salah satu media yang dapat meningkatkan kasus kematian akibat COVID-19.

Tujuan: Studi pustaka ini bertujuan untuk menganalisis paparan jangka panjang $\mathrm{PM}_{2.5}$ dalam meningkatkan risiko kematian akibat COVID-19.

Metode: Menggunakan metode literature review dengan pencarian artikel penelitian yang relevan sesuai dengan variable dan tujuan dalam penulisan.

Hasil: $\mathrm{PM}_{2.5}$ diindikasi menyumbangkan jumlah kasus kesakitan dan kematian pada kasus COVID-19. $\mathrm{PM}_{2.5}$ yang memiliki ukuran kecil berdiameter $\leq 2.5 \mu \mathrm{m}$ dan dapat menyerap racun, dapat masuk ke dalam paru-paru bagian dalam hingga menyebabkan berbagai penyakit pernapasan hingga kematian. Beberapa penelitian menemukan bahwa terdapat hubungan berbanding lurus antara peningkatan $\mathrm{PM}_{2.5}$ dan peningkatan kasus kematian COVID-19.

Kesimpulan: $\mathrm{PM}_{2.5}$ memiliki andil dalam meningkatkan risiko kematian akibat COVID-19, karena konsentrasi $\mathrm{PM}_{2.5}$ yang diatas nilai ambang batas dapat menyebabkan berbagai penyakit pernapasan terhadap orang-orang yang sering terpapar $\mathrm{PM}_{2.5}$ dalam jangka waktu yang lama sehingga dapat memiliki penyakit kronis dan dapat menyebabkan imunitas menurun. Jika dikaitkan dengan COVID-19, pasien COVID-19 yang memiliki riwayat penyakit kronis akan memiliki risiko kematian yang lebih tinggi.
\end{abstract}

Kata kunci: COVID-19, Kasus Kematian, Pandemi, $\mathrm{PM}_{2.5}$

\begin{abstract}
Background: The number of cases from May 5, 2021, there are 154,815,600 confirmed cases of COVID-19, including 3,236,104 deaths worldwide. PM2.5 is suspected as one of the media that can increase cases of death due to COVID-19.

Objectives: This literature study aims to analyze long-term exposure to $P M_{2.5}$ in increasing the risk of death from COVID-19.

Methods: Using the literature review method by searching for relevant research articles in accordance with the variables and objectives in writing.

Results: PM 2.5 has a role in increasing the risk of death from COVID-19, because PM 2.5 sconcentrations above the threshold value can cause various respiratory diseases in people who are often exposed to PM2.5 for a long time so that they can have chronic disease and can cause decreased immunity. If it is linked to COVID-19, COVID-19 patients who have a history of chronic disease will have a higher risk of death
\end{abstract}

Keywords: Case of Death, COVID-19, Pandemic, PM 2.5

\footnotetext{
*Koresponden:

tri.meidyarahma@gmail.com

Tri Meidya Rahmawati
} 
${ }^{1}$ Departemen Kesehatan Lingkungan, Fakultas Kesehatan Masyarakat, Universitas Airlangga, Kampus C Mulyorejo, 60115, Surabaya, Jawa Timur, Indonesia

\section{PENDAHULUAN}

Coronavirus Disease 2019 (COVID-19) adalah penyakit yang disebabkan oleh virus corona jenis baru. 'CO' diambil dari corona, 'VI' virus, dan 'D' disease (penyakit). Sebelumnya, penyakit ini bernama '2019 novel coronavirus' atau '2019-nCoV.' (World Health Organization, 2020). Virus Corona digolongkan dalam subfamily Coronavirinae, family Coronaviridae, order Nidovirales. Terdapat empat genera virus Corona yaitu Alphacoronavirus $(\alpha \mathrm{CoV})$, Betacoronavirus $(\beta \mathrm{CoV})$, Deltacoronavirus $(\delta \mathrm{CoV})$ dan Gammacoronavirus $(\gamma \mathrm{CoV})$ (Isbaniah and Susanto, 2020). Berdasarkan hasil filogenetik menunjukkan bahwa virus ini masuk ke dalam subgenus yang sama dengan coronavirus yang menyebabkan wabah Severe Acute Respiratory Syndrome (SARS). International Commite on Taxonomy of Viruses berdasarkan hal tersebut mengajukan nama SARSCoV-2 pada virus ini (Gorbalenya et al., 2020). Berikut beberapa kasus terkonfirmasi COVID-19 di seluruh Dunia hingga menyebabkan kasus kematian yang tinggi.

Menurut data dari situs Organisasi Kesehatan Dunia atau World Health Organization (WHO) Wabah COVID-19 pertama kali terjadi di Wuhan, Provinsi Hubei, China pada Desember 2019. Terhitung 5 Mei 2021 terdapat 154.815.600 kasus yang terkonfirmasi COVID-19, dengan jumlah kasus kematian yang berjumlah 3.236.104 kasus yang tersebar di seluruh dunia. Selama rentang waktu penelitian dalam jurnal yang digunakan di literature review, angka kasus tertinggi terdapat di tiga Benua yakni Amerika, Eropa dan Asia. Kasus terkonfirmasi COVID-19 yang terjadi di wilayah Benua Amerika berjumlah 62.910.688 kasus. Pada wilayah Benua Amerika kasus terbanyak terjadi di Negara Amerika Serikat dengan jumlah kasus terkonfirmasi COVID19 sebanyak 32.167.970. Wilayah Benua Eropa terdapat kasus terkonfirmasi COVID-19 sebanyak 52.441.169 kasus dan pada wilayah Benua Eropa kasus terbanyak terjadi di Negara Perancis dengan jumlah kasus terkonfirmasi COVID-19 sebanyak 5.616.180 kasus. Wilayah Benua Asia terdapat kasus terkonfirmasi COVID19 sebanyak 24.269.169 kasus dan pada wilayah Benua Asia kasus terbanyak terjadi di Negara India dengan jumlah kasus terkonfirmasi COVID-19 sebanyak 21.077.410 kasus (World Health Organization, 2021).

Polusi udara yang mengandung bahan partikulat diperkirakan dapat menjadi penyebab penambahan kasus COVID-19 dan dapat menjadi faktor yang dapat memperparah keadaan pasien COVID-19. Terdapat berbagai literatur yang menunjukkan bahwa paparan polusi udara akan meningkatkan jumlah kematian dan menyebabkan orang menderita penyakit pernafasan (Persicoa and Johnson, 2021). Penelitian yang telah dilakukan sebelumnya menunjukkan bahwa paparan jangka panjang dari polusi udara dikaitkan dengan peningkatan prevalensi penyakit pernapasan dan kematian (Mursinto and Kusumawardani, 2016). Pada penelitian yang dilakukan di wilayah Italia Utara, penyebaran wabah SARS-CoV-2 pertama kali terjadi di sekitar kawasan industri yang paling tercemar di negara tersebut dan merupakan kawasan paling tercemar di Eropa, hal ini menunjukkan bahwa terdapat kaitan antara polusi udara dan COVD-19 (Filippini et al., 2021). Beberapa negara seperti Cina, India, Italia, dan Amerika Serikat juga menunjukkan adanya korelasi positif antara tingkat polusi udara yang tinggi dengan tingkat keparahan / kematian akibat infeksi COVID-19 (Paital and Agrawal, 2020). Hal ini sejalan dengan hasil data particulate matter berdiameter 2.5 mikron $\left(\mathrm{PM}_{2.5}\right)$ yang ditunjukkan di Benua Asia yang rata-rata telah melebihi nilai ambang batas pedoman yang berlaku (Gupta et al., 2020).

Paparan polusi particulate matter (PM) telah dilaporkan meningkatkan risiko mortalitas dan morbiditas penyakit kardiopulmoner di seluruh dunia sedangkan penelitian baru dari Cina menyebutkan bahwa paparan jangka pendek dari $\mathrm{PM}_{2.5}$ secara signifikan menyebabkan kasus terkonfirmasi COVID-19. PM 2.5 adalah campuran kompleks dari berbagai komponen kimia yang terbentuk di atmosfer, oleh karena itu karakterisasi kimianya didasarkan pada analisis kimia secara simultan. Jenis elemen pada atmosfer antara lain arsen (As), kadmium (Cd), tembaga (Cu), nikel (Ni), seng ( $\mathrm{Zn})$, vanadium (V), merkuri $(\mathrm{Hg})$ dan timbal $(\mathrm{Pb})$ (Kusmartini et al., 2019). $\mathrm{PM}_{2.5}$ dapat menembus bagian paru paling dalam karena memiliki ukuran yang kecil. Sehingga $\mathrm{PM}_{2.5}$ dapat menyebabkan berbagai gangguan pernafasan akut yaitu Insfeksi saluran pernapasan akut (ISPA), kanker paru-paru, kardiovaskular, kematian dini, dan penyakit paru-paru obstruktif kronis (Song, Zhang and Dai, 2019). Orang yang telah terkonfirmasi COVID-19 akan memiliki kondisi kesehatan yang semakin buruk karena terpapar polusi udara secara konsisten, dimana yang selama ini diketahui polusi udara sebagai penyebab utama penyakit pernapasan (Petrosillo et al., 2020). Penelitian yang dilakukan di Kanada melaporkan adanya hubungan $\mathrm{PM}_{2.5}$ dan insiden COVID-19 (Stieb et al., 2020). Korelasi yang sangat signifikan antara konsentrasi $\mathrm{PM}_{2.5}$ dan kejadian mortalitas dan tingkat kematian COVID-19 juga ditemukan di Provinsi Italia (Borro et al., 2020).

Tujuan dari artikel review ini adalah untuk menganalisis paparan jangka panjang $\mathrm{PM}_{2.5}$ dalam meningkatkan risiko kematian akibat COVID-19, sehingga diharapkan dapat memberikan sumbangan pemikiran ilmiah bagi para pemangku kebijakan terkait dengan harapan kedepannya dapat digunakan sebagai pandangan ketika akan membuat suatu kebijakan. 


\section{METODE}

Artikel ini menggunakan metode literature review dengan pencarian artikel penelitian yang relevan sesuai dengan variabel dan tujuan dalam penulisan. Pencarian artikel yang relevan dengan tujuan penulisan artikel ini diperoleh dari beberapa sumber database elektronik, yaitu: ScienceDirect, ProQuest, PubMed dan Google Scholar. Kata kunci yang digunakan dalam pencarian artikel yaitu: polusi udara dan kasus COVID-19. Artikel yang digunakan sebelumnya dilakukan penyaringan berdasarkan kriteria inklusi yang ditentukan oleh penulis dari setiap jurnal yang diambil. Adapun kriteria inklusi pengumpulan jurnal sebagai berikut :

1. Tahun sumber literatur yang diambil mulai tahun Desember 2019 - Januari 2021.

2. Penelitian yang membahas kematian COVID-19 serta hubungannya dengan peningkatan polusi udara dan karakteristik individu.

3. Artikel dapat di akses full text

4. Original riset

5. Jurnal Indonesia minimal terindex Sinta 3 atau SCOPUS.

6. Penelitian dilakukan di tiga benua, yaitu Benua Asia, Benua Amerika Utara, dan Benua Eropa.

Berdasarkan penelusuran yang dilakukan, ditemukan 50 jurnal. Setelah diseleksi sesuai dengan kriteria inklusi, didapatkan 12 jurnal full text yang sesuai untuk ditinjau.

\section{DISKUSI}

Patogen penyebab COVID-19 disebabkan oleh virus SARS-CoV-2 yang sangat menular dan bersifat patogen serta menyerang sistem pernapasan. Penularan virus ini dapat melalui sekresi dari orang yang terinfeksi, misalnya air liur yang dapat memalui droplet atau percikan pernapasan saat orang terinfeksi batuk, bersin, berbicara, atau bernyanyi, dan juga dapat melalui micrordroplet yang memiliki potensi menyebar pada jarak yang lebih jauh, dan dapat melalui permukaan yang terkontaminasi (Kementrian Kesehatan Republik Indonesia, 2020).

Pada banyak kasus virus ini dapat ditularkan dari manusia ke manusia yang lainnya dan juga menimbulkan gejala seperti pilek, radang paru-paru, bahkan gangguan pernapasan akut syndrome (ARDS), yang dimana gejala ini mirip seperti gejala pada penyakit SARS dan Middle-East Respiratory Syndrome (MERS) (Guan et al., 2020) (Yang et al., 2020). Masing-masing orang memiliki respon yang berbeda-beda terhadap penyakit COVID-19. Sebagian besar orang yang terinfeksi akan mengalami berbagai gejala, dari gejala ringan hingga gejala yang sedang. Gejala yang paling umum dirasakan oleh banyak orang adalah demam, batuk kering, dan kelelahan. Sedangkan gejala yang hanya sedikit orang rasakan adalah rasa tidak nyaman dan nyeri, nyeri tenggorokan, diare, konjugtivitas (mata merah), sakit kepala, hilangnya indera perasa atau penciuamn, dan ruam pada kulit, atau perubahan warna pada jari tangan atau jari kaki (World Health Organizationn, 2021).

Namun, terdapat juga gejala berat seperti gangguan organ, syok septik, dan pneumonia yang berakibat fatal. Kasus kematian akibat COVID-19 dapat terjadi apabila tidak dilakukan penanganan segera dan secara maksimal. Hal ini dikarenakan pasien terkonfirmasi COVID-19 harus mendapatkan perawatan yang intensif di rumah sakit agar bisa dipantau keadaan kesehatannya dan agar mendapatkan pengobatan yang tepat (Firmansyah et al., 2020).

Ada berbagai faktor yang diindikasi dapat menjadi faktor kematian akibat COVID-19, salah satunya adalah penyakit penyerta atau komorbid. Lporan terbaru menunjukkan bahwa kondisi kronis seperti hipertensi, penyakit kardiovaskular, diabetes militus, merokok, penyakit pernapasan obstruktif kronis (PPOK), dan ginjal kronis merupakan penyebab utama yang paling sering terjadi diantara pasien terkonfirmasi COVID-19 (Iaccarino et al., 2020).

Selain komorbid, ada juga faktor lingkungan yang dapat menjadi faktor kematian akibat COVID-19, seperti suhu di udara ambien, polusi udara, kelembapan, dan cuaca. Dalam penelitian di Italia, kota-kota yang memiliki polusi udara ambien yang tinggi, memiliki jumlah kasus konfirmasi dan kasus kematian COVID-19 yang lebih tinggi. Meskipun penularan COVID-19 masih butuh penelitian yang lebih lanjut, namun kenyataan dari adanya peningkatan COVID-19 berbanding lurus dengan peningkatan AQI (penurunan kualitas udara), $\mathrm{PM}_{2.5}, \mathrm{NO}_{2}$, dan penurunan suhu di udara ambien (Li et al., 2020; Coccia, 2020).

$\mathrm{PM}_{2.5}$ merupakan salah satu jenis pencemar udara dengan diameter $\leq 2.5 \mu \mathrm{m}$, memiliki ciri-ciri ukuran partikelnya yang sangat kecil (Du et al., 2018) dengan permukaan yang luas dan kemampuan dalam menyerap racun (Kim et al., 2018). Disebutkan bahwa $\mathrm{PM}_{2.5}$ merupakan campuran yang terdiri dari partikel padat dan cair, termasuk karbon hitam, logam, nitrat, sulfat, hidrokarbon aromatic polisiklik, dan partikel dari knalpot mobil. Jika merujuk pada pedoman WHO tentang Air Quality Guidelines For Particulate Matter, Ozone, Nitrogen Dioxide And Sulfur Dioxide, ambang batas aman paparan $\mathrm{PM}_{2.5}$ adalah $25 \mu \mathrm{g} / \mathrm{m}^{3} / 24 \mathrm{jam}$. Apabila $\mathrm{PM}_{2.5}$ melebihi dari nilai ambang batas yang telah ditetapkan, maka besar kemungkinan dapat menyebabkan berbagai gangguan pernapasan seperti penyakit asma, penyakit paru obstruktif kronik (PPOK), kanker paru (Li, Zhou and Zhang, 2018), hingga penyakit jantung. $\mathrm{PM}_{2.5}$ dapat menyebabkan keparahan terhadap penyakit-penyakit tersebut hingga 
menyebabkan kematian dini. Hal ini menunjukkan bahwa $\mathrm{PM}_{2.5}$ dapat menyebabkan berbagai penyakit komorbid yang selanjutnya dapat meningkatkan faktor risiko kematian COVID-19. Risiko lain paparan konis jangka panjang dari $\mathrm{PM}_{2.5}$ di wilayah metropolitan kemungkinan akan memiliki peran yang cukup signifikan dalam penyebaran COVID-19.

Hal tersebut didukung dengan pernyataan bahwa PM dapat bertindak sebagai pembawa utama dari droplet, yang dapat meningkatkan penularan virus. Penularan COVID-19 dari udara yang telah terkontaminasi merupakan penularan yang cepat dibandingkan dengan penularan dari manusia ke manusia (Urrutia-Pereira, Mello-da-Silva and Solé, 2020). Adanya interaksi langsung antara polusi udara dengan virus yang berada di atmosfer. Virus yang telah menempel di partikulat akan dilindungi dari penurunan radiasi ultra violet (UV), ozon, (Hutter et al., 2020) atau faktor lingkungan yang lainnya, akibatnya kelangsungan hidup virus di lingkungan akan lebih panjang. Sehingga partikulat berfungsi membawa virus, dan menyebabkan pengendapan di paru-paru (Setti, Passarini, De Gennaro, et al., 2020).

Lebih jauh, aerosol juga dianggap dapat menjadi salah satu jalur masuk penularan COVID-19, karena aerosol dapat membawa virus dan bisa bertahan hidup hingga 3 jam. Penyakit pernapasan dapat diinduksi oleh aerosol yang memfasilitasi virus dalam menginfeksi dan meningkatkan morbiditas atau keparahan pada pasien telah terinfeksi (Paital, 2020; (Sarmadi et al, 2020). Sebagian besar aerosol yang ditemukan di udara dihasilkan dari aktivitas antropogenik yang menghasilkan partikel-partikel yang sangat halus. Apabila jumlah aerosol semakin bertambah, dapat meningkatkan tingkat polusi udara. Disisi lain, aerosol dapat menyebabkan risiko kesehatan terhadap manusia. Studi sebelumnya menyatakan bahwa SARS-CoV-2 tidak secara spesifik teradsorpsi atau diserap oleh permukaan. Namun, dapat menempel pada permukaan apapun mulai dari kertas karton, plastik, koin, logam, pakaian, aerosol, dan lain-lain dan virulensi virus dapat bertahan beberapa jam hingga beberapa hari pada bahan aerosol (Chin et al., 2020). Sehingga aerosol juga dapat dimodifikasi pada PM di udara.

Hasil dari penelitian menunjukkan bahwa setiap adanya peningkatan konsentrasi $\mathrm{PM}_{2.5}$ akan diikuti dengan kenaikan kasus kematian COVID-19. Di Amerika Serikat, sebuah studi yang baru dirilis dari Harvard TH Chan School of Public Health menggunakan data yang dikumpulkan dari sekitar 3000 negara bagian AS untuk menyelidiki apakah paparan rata-rata jangka panjang $\mathrm{PM}_{2.5}$ meningkatkan risiko kematian akibat COVID19, dan ditemukan bahwa setiap peningkataan konsentrasi $\mathrm{PM}_{2.5}$ sebesar $1 \mu \mathrm{g} / \mathrm{m}^{3}$ dapat meningkatkan kematian akibat COVID-19 sebesar 15\% (Brandt et al, 2020). Hal ini dapat terjadi karena, COVID-19 disebabkan oleh SARS-CoV-2, dimana studi sebelumnya menyatakan bahwa SARS-CoV-2 memiliki 50\% dan $79 \%$ urutan nukleotida yang sama dengan genom SARS-CoV-1 dan MERS-CoV (Andersen et al., 2020) dan memiliki pengubah reseptor-angiotensin yang sama yaitu Angiotensin-Converting Enzyme 2 (ACE 2), yang pada tahun 2003 mengakibatkan peningkatan risiko kematian sebesar 84\% akibat SARS di wilayah China yang memiliki konsentrasi $\mathrm{PM}_{2.5}$ \& $\mathrm{PM}_{10}$ lebih mendominasi (Zhou et al., 2020).

Paparan jangka panjang atau pendek dari konsentrasi $\mathrm{PM}_{2.5}$ yang berada di luar ruangan maupun di dalam ruangan berpotensi menyebabkan penyakit pernapasan salah satunya adalah PPOK. Penyakit pernapasan kronis ini dapat membuat seseorang rentan terhadap infeksi dan dapat menjadi faktor risiko memperparah penyakit jika terjadi infeksi. Dalam hal ini, orang yang sudah memiliki komorbid PPOK akan membutuhkan pengobatan untuk menyehatkan kembali sistem kekebalan tubuh. Obat-obatan yang dibutuhkan mengandung ACE 2 dan Angiotensin Receptor Blocker (ARB). ACE 2 dan ARB merupakan membrane protein yang bertugas sebagai pelindung atau memperoteksi paru-paru, namun obat ini dapat memicu masuknya SAR-CoV-2 atau virus corona (Driggin et al., 2020) ke dalam tubuh melalui paru-paru. Hal ini disebabkan karena ACE 2 merupakan jalan masuknya SAR-CoV-2. Protein ACE-2 bertindak sebagai reseptor untuk pelekatan protein "S" yang ada pada SAR-CoV-2. Protein S dapat meningkatkan kemungkinan infeksi serta tingkat keparahan penyakit pada manusia. Pada penelitian sebelumnya menyatakan bahwa penurunan sistem kekebalan tubuh yang disebabkan paparan jangka panjang ataupun paparan jangka pendek dari konsentrasi $\mathrm{PM}_{2.5}$ dapat berkonstribusi terhadap kematian SARS-CoV-2 di wilayah Milan (Zoran et al., 2020)

$\mathrm{PM}_{2.5}$ dapat menjadi faktor yang berkontribusi dalam penularan COVID-19 di udara, ini terjadi karena $\mathrm{PM}_{2.5}$ menyerang paru-paru dan organ pernapasan yang dimana jalur masuk COVID-19 juga melalui pernapasan. Sehingga akan memungkinkan COVID-19 dengan mudah masuk ke pernapasan bersamaan dengan $\mathrm{PM}_{2.5}$.

Berdasarkan penelitian-penelitian diatas diketahui bahwa negara-negara yang memiliki kasus konfirmasi COVID-19 yang cukup tinggi dapat dikatakan memiliki hubungan yang signifikan antara paparan jangka panjang $\mathrm{PM}_{2.5}$ dan CFR COVID-19, ini menunjukkan bahwa paparan jangka panjang $\mathrm{PM}_{2.5}$ sebelum periode epidemic dapat meningkatkan kerentanan populasi terhadap SARS-CoV-2. Hal ini sejalan dengan ditemukannya bukti bahwa adalah pembawa atau vector pengangkut yang efisien untuk virus SARS-CoV-2, dan juga pendorong masuknya virus ke saluran pernapasan yang dapat menyebabkan infeksi (Setti, Passarini, de Gennaro, et al., 2020).

Disisi lain, terdapat penelitian yang menyatakan bahwa diberlakukannya "lockdown" karena COVID-19 berdampak positif terhadap berkurangnya polusi udara (Bashir et al., 2020), selain itu kematian akibat COVID19 dapat dihindari (Venter et al., 2020). Hasil penelitian di China menunjukkan pelaksanaan lockdown 
menyebabkan penurunan polusi udara secara signifikan, hal ini berbanding lurus dengan penurunan jumlah kematian akibat COVID-19 (Kai Chen et al., 2020).

Intervensi jangka panjang terhadap pengendalian polusi udara selama pandemik diperlukan. Hal ini karena berdasarkan studi literatur yang dilakukan, polusi udara yang buruk akan menjadi penyebab utama penularan COVID-19. Di Indonesia belum ada penelitia terkait PM $_{2.5}$ dengan COVID-19, diharpakan dapat dilakukan penelitian untuk mengetahui tingginya insiden COVID-19 yang ada di Indonesia yang disebabkan oleh faktor $\mathrm{PM}_{2.5}$.

Meskipun demikian, penyakit terkait polusi memiliki korelasi positif dengan tingkat keparahan dan kematian pada pasien COVID-19, sehingga rekomendasi penggunaan masker yang tepat bahkan di dalam ruangan di mana polusi udara dan COVID-19 biasa terjadi. Karena itu, beberapa literatur-literatur baru menyimpulkan bahwa penggunaan "masker wajah yang dapat menyaring polusi udara" harus digunakan sebagai salah satu tindakan pencegahan terhadap COVID-19 di tempat umum maupun di dalam ruangan di mana polusi udara sangat tinggi. Oleh karena itu, organisasi seperti WHO merekomendasikan penggunaan masker wajah untuk orang yang mengalami gejala pernapasan yang berguna untuk mengurangi faktor risiko penularan ke orang lain. Rekomendasi penggunaan masker juga diperuntukkan untuk lansia, penderita penyakit komorbid yang rentan terhadap COVID-19, orang-orang yang tanpa gejala maupun pra-gejala guna mencegah penularan COVID-19. Membersihkan tangan menggunakan sabun dan air mengalair atau menggunanakan hand sanitizier juga dapat membantu menghilangkan virus.

Hal lain yang dapat dilakukan oleh pemerintah dalam meningkatakan pencegahan penularan COVID-19 adalah merumuskan regulasi untuk mencegah penyebaran atau kematian akibat COVID-19. Contoh regulasi tersebut adalah pengadaan Alat Pelindung Diri (APD), pemeriksaan, isolasi, dan asuransi kesehatan.

Pemerintah dapat merumuskan regulasi peningkatan kualitas udara untuk mencegah peningkatan polusi udara, contohnya adalah dengan meningkatkan kualitas bahan bakar minyak (BBM), meningkatkan kualitas mesin dan mengendalikan kepadatan lalu lintas.

\section{KESIMPULAN}

Tingkat polusi udara yang berasal dari $\mathrm{PM}_{2.5}$ memiliki andil dalam meningkatkan risiko kematian akibat COVID-19, karena konsentrasi $\mathrm{PM}_{2.5}$ yang diatas nilai ambang batas dapat menyebabkan berbagai penyakit pernapasan terhadap orang-orang yang sering terpapar $\mathrm{PM}_{2.5}$ dalam jangka waktu yang lama sehingga dapat memiliki penyakit kronis dan dapat menyebabkan imunitas menurun. Jika dikaitkan dengan COVID-19, pasien COVID-19 yang memiliki riwayat penyakit kronis akan memiliki risiko kematian yang lebih tinggi.

Oleh karena itu, intervensi klinis dan lingkungan disarankan untuk mengendalikan COVID-19 di negaranegara di mana penyakit pandemi dan polusi udara sering terjadi. Berdasarkan tingkat polusi udara, disarankan setiap negara membuat perencanaan terhadap pengendalian polusi udara.

\section{ACKNOWLEDGEMENT}

Ucapan terima kasih saya sampaikan atas terbitnya artikel ini kepada pihak-pihak yang terlibat dalam keberhasilan penulisan literature review ini, kususnya kepada pembimbing atas bimbingan dan nasihatnya dalam penulisan artikel ini.

\section{REFERENSI}

Andersen, K. G., Rambaut, A., Lipkin, W. I., Holmes, E.C., and Garry, R. F. (2020) 'The Proximal Origin Of SARS-CoV-2', Nature Medicine, 26(4), Pp. 450-452. Doi: 10.1038/S41591-020-0820-9.

Bashir, M. F., MA, B. J., Bilal., Komal, B., Bashir, M.A., Farooq, T. H., Iqbal, N., and Bashi, M. (2020) 'Correlation Between Environmental Pollution Indicators and COVID-19 Pandemic A Brief Study in Californian Context', Environmental Research, 187, p. 109652. doi: 10.1016/j.envres.2020.109652.

Borro, M.. Di Girolamo, P., Gentile, G., De Luca, O., Preissner, R., Marcolongo, A., Ferracuti, S., and Simmaco, M. (2020) 'Evidence-Based Considerations Exploring Relations Between Sars-CoV-2 Pandemic And Air Pollution: Involvement Of $\mathrm{PM}_{2.5}$-Mediated Up-Regulation Of The Viral Receptor ACE-2', International Journal of Environmental Research and Public Health, 17(15), pp. 1-13. doi: 10.3390/ijerph17155573.

Brandt, E. B., Beck, A. F. and Mersha, T. B. (2020) 'Air Pollution, Racial Disparities, And COVID-19 Mortality', Journal of Allergy and Clinical Immunology. Elsevier Inc., 146(1), pp. 61-63. doi: 10.1016/j.jaci.2020.04.035.

Chin, A. W. H., Chu, J. T. S., Perera, M. R A., Hui, K. P. Y., Yen, H. L., Chan, M. C. W., Peiris, M., and Poon, L. L. M. (2020) 'Stability of SARS-CoV-2 In Different Environmental Conditions', Lancet Microbe, 1(1). doi: 10.1016/S2666-5247(20)30003-3.

Coccia, M. (2020) 'How Do Low Wind Speeds And High Levels Of Air Pollution Support The Spread of 
COVID-19?', Atmospheric Pollution Research. Turkish National Committee for Air Pollution Research and Control, 12(1), pp. 437-445. doi: 10.1016/j.apr.2020.10.002.

Coker, E. S., Cavalli, L., Fabrizi, E., Guastella, G., Lippo, E., Parisi, M. L., Pontarollo, N., Rizzati, M., Varacca, A., and Vergalli, S. (2020) 'The Effects of Air Pollution on COVID-19 Related Mortality in Northern Italy', Environmental and Resource Economics. Springer Netherlands, 76(4), pp. 611-634. doi: 10.1007/s10640-020-00486-1.

Cole, M. A., Ozgen, C. and Strobl, E. (2020) Air Pollution Exposure and COVID-19 in Dutch Municipalities, Environmental and Resource Economics. Springer Netherlands. doi: 10.1007/s10640-020-00491-4.

Driggin, E., Madhavan, M. V., Bikdeli, B., Chuich, T., and Harm, P D. (2020) 'Cardiovascular Considerations For Patients, Health Care Workers, And Health Systems During The Coronavirus Disease 2019 (COVID19) pandemic', Journal of the American College of cardiology, 75(18), pp. 2352-2371. doi: 10.1016/j.jacc.2020.03.031.

Du, P., Du, R., Ren, W., Lu, Z., and Fu, P. (2018) 'Seasonal Variation Characteristic Of Inhalable Microbial Communities In PM2.5 In Beijing City, China', Science of the Total Environment. Elsevier B.V., 610611(September), pp. 308-315. doi: 10.1016/j.scitotenv.2017.07.097.

Fareed, Z., Iqbal, N., Shahzad, F., Shah, S. G. M., Zulfiqar, B., Shahzad, K., Hashmi, S. H., and Shahza, U. (2020) 'Co-Variance Nexus Between COVID-19 Mortality, Humidity, And Air Quality Index In Wuhan, China: New Insights From Partial And Multiple Wavelet Coherence', Quality, Atmosphere \& Health, 13(6).

Filippini, T., Rothman, K. J., Cocchio, S., Narne, E., Mantoan, D., Saia, M., Goffi, A., Ferrari, F., Maffeis, G., Orsini, N., Baldo, V., and Vinceti, M. (2021) 'Associations Between Mortality From COVID-19 In Two Italian Regions And Outdoor Air Pollution As Assessed Through Tropospheric Nitrogen Dioxide', Science of the Total Environment, 760(xxxx). doi: 10.1016/j.scitotenv.2020.143355.

Firmansyah, H., Fadlillah, A. N. and Pawitra, A. S. (2020) 'Particulate Matter as a Driven Factor Covid19 Transmission at Outdoor: Review', Jurnal Kesehatan Lingkungan, 12(3), p. 225. doi: 10.20473/jkl.v12i3.2020.225-234.

Frontera, A., Cianfanelli, L., Vlachos, K., Landoni, G., \& Cremona, G. (2020) 'Severe Air Pollution Links To Higher Mortality In COVID-19 Patients: The "Double-Hit" Hypothesis.', Journal of Infection. Elsevier Ltd, 81(2), pp. 255-259. doi: 10.1016/j.jinf.2020.05.031.

Gorbalenya, A. E. Baker, S. C., Baric, R. S., de Groot, R. J., Drosten, C., Gulyaeva, A. A.,Haagmans, B. L., Lauber, C., Leontovich, A. M., Neuman, B. W., Penzar, D., Perlman, S., Poon, L. L. M., Samborskiy, D. V., Sidorov, I. A., Sola, I., and Ziebuhr, J. (2020) 'The Species Severe Acute Respiratory Syndromerelated Coronavirus: Classifying 2019-Ncov And Naming It SARS-CoV-2', Nature Microbiology, 5(4), pp. 536-544. doi: 10.1038/s41564-020-0695-z.

Guan, W., Ni, Z., Hu, Y., Liang, W., Ou, C., He, J., Liu, L., Shan, H., Lei, C., Hui, D. S.C., Du, B., Li, L., Zeng, G., Yuen, K., Chen, R., Tang, C., Wang, T., Chen, P., Xiang, J., Li, S., Wang, J., Liang, Z., Peng, Y., Wei, L., Liu, Y., Hu, Y., Peng, P., Wang, J., Liu, J., Chen, Z., Li, G., Zheng, Z., Qiu, S., Luo, J., Ye, C., Zhu, S., and Zhong, N. (2020) 'Clinical Characteristics of Coronavirus Disease 2019 in China', New England Journal of Medicine, 382(18), pp. 1708-1720. doi: 10.1056/nejmoa2002032.

Gupta, A., Bherwani, H., Gautam, S., Anjum, S., Musugu, K., Kumar, N., Anshul, A., \& Kumar, R. (2020) 'Air pollution aggravating COVID-19 lethality? Exploration in Asian cities using statistical models', Environment, Development and Sustainability. Springer Netherlands, 22(8). doi: 10.1007/s10668-02000878-9.

Hendryx, M. and Luo, J. (2020) 'COVID-19 prevalence and fatality rates in association with air pollution emission concentrations and emission sources', Environmental Pollution. Elsevier Ltd, 265(A). doi: 10.1016/j.envpol.2020.115126.

Hutter, H. P., Poteser, M., Moshammer, H., Lemmerer, K., Mayer, M., Weitensfelder, L., Wallner, P., and Kundi, M. (2020) 'Air Pollution Is Associated With Covid-19 Incidence And Mortality In Vienna, Austria', International Journal of Environmental Research and Public Health, 17(24), pp. 1-11. doi: 10.3390/ijerph17249275.

Iaccarino, G., Grassi, G., Borghi, C., Ferri, C., Salvetti, M., \& Volpe. M. M. (2020) 'Age And Multimorbidity Predict Death Among COVID-19 Patients: Results Of The SARS-RAS Study Of The Italian Society Of Hypertension', Hypertension, 76(2), pp. 1-7. doi: 10.1161/HYPERTENSIONAHA.120.15324.

Isbaniah, F. and Susanto, A. D. (2020) 'Pneumonia Corona Virus Infection Disease -19 ( COVID-19 )', J Indon Med Assoc, 70(4), pp. 87-94.

Jiang, Y. and $\mathrm{Xu}$, J. (2020) 'The association between COVID-19 deaths and short-term ambient air pollution/meteorological condition exposure: a retrospective study from Wuhan, China', Air Quality, Atmosphere and Health. Air Quality, Atmosphere \& Health. doi: 10.1007/s11869-020-00906-7. 
Kai, C., Wang, M., Huang, C., Kinney, P. L., and Anastas, P. T. (2020) 'Air Pollution Reduction And Mortality Benefit During The COVID-19 Outbreak In China', Lancet Planet Helath, 4(6), pp. 19-21. doi: 10.1016/S2542-5196(20)30107-8.

Kementrian Kesehatan Republik Indonesia (2020) Pertanyaan dan Jawaban Terkait COVID-19 Kementerian Kesehatan, Kementrian Kesehatan Republik Indonesia. Available at: https://www.kemkes.go.id/article/view/20030400008/FAQ-Coronavirus.html.

Kim, Y., Seo, J., Kim, J. Y., Lee, J. Y., Kim, H., and Kim, B. M. (2018) 'Characterization Of PM2.5 And Identification Of Transported Secondary And Biomass Burning Contribution In Seoul, Korea', Environmental Science and Pollution Research. Environmental Science and Pollution Research, 25(5), pp. 4330-4343. doi: 10.1007/s11356-017-0772-x.

Kusmartini, I., Adventini, N., Sari, D. K., Kurniawati, S., Lestiani, D. D., and Santoso, M. (2019) 'Karakterisasi Unsur Pm 2,5 Pada Periode Kebakaran Hutan Di Pekanbaru Dengan Teknik Analisis Aktivasi Neutron', Jurnal Sains dan Teknologi Nuklir Indonesia, 20(1), p. 29. doi: 10.17146/jstni.2019.1.1.4655.

Li, H., Xu, X., Dai, D., Huang, Z., Ma, Z., and Guan, Y. (2020) 'Air Pollution And Temperature Are Associated With Increased COVID-19 Incidence: A Time Series Study', International Journal of Infectious Diseases, 97, p. 278=282. doi: 10.1016/j.ijid.2020.05.076.

Li, R., Zhou, R. and Zhang, J. (2018) 'Function of PM2.5 in the pathogenesis of lung cancer and chronic airway inflammatory diseases', Oncology Letters, 15(5), pp. 7506-7514. doi: 10.3892/ol.2018.8355.

Meo, Sultan A., Abukhalaf, A. A., Ali A., Alessa, O. M., Sami, W., \& Klonoff, D. C. (2020) 'Effect of Environmental Pollutants PM-2.5, Carbon Monoxide, and Ozone on the Incidence and Mortality of SARS-COV-2 Infection in Wildfire Affected Ten Counties in California', Science of The Total Environment. The Author(s). Published by Elsevier B.V, p. 143948 . doi: 10.1016/j.scitotenv.2020.143948.

Meo, S. A. Abukhalaf, A. A., Ali A., \& Alessa, O. M. (2020) 'Wildfire and COVID-19 pandemic: Effect of environmental pollution PM-2.5 and carbon monoxide on the dynamics of daily cases and deaths due to SARS-COV-2 infection in San-Francisco USA', European Review for Medical and Pharmacological Sciences, pp. 10286-10292. doi: 10.26355/eurrev_202010_23253.

Mursinto, D. and Kusumawardani, D. (2016) 'Estimasi Dampak Ekonomi Dari Pencemaran Udara Terhadap Kesehatan Di Indonesia', Jurnal Kesehatan Masyarakat, 11(2), pp. 163-172. doi: 10.15294/kemas.v11i2.3677.

Paital, B. (2020) 'Nurture to nature via COVID-19, a self-regenerating environmental strategy of environment in global context', Science of the Total Environment. Elsevier B.V., 729, p. 139088. doi: 10.1016/j.scitotenv.2020.139088

Paital, B. and Agrawal, P. K. (2020) 'Air pollution by NO2 and PM2.5 explains COVID-19 infection severity by overexpression of angiotensin-converting enzyme 2 in respiratory cells: a review', Environmental Chemistry Letters. Springer International Publishing, 19(1), pp. 1-18. doi: 10.1007/s10311-020-01091-w.

Persicoa, C. L. and Johnson, K. R. (2021) 'The effects of increased pollution on COVID-19 cases and deaths', Journal of Environmental Economics and Management. Elsevier Inc. doi: 10.1016/j.jeem.2021.102431.

Petrosillo, N., Viceconte, G., Ergonul, O., Ippolito, G., and Petersen, E. (2020) 'COVID-19, SARS and MERS: Are They Closely Related?', Clinical Microbiology and Infection. Elsevier Ltd, 26(6), pp. 729-734. doi: 10.1016/j.cmi.2020.03.026.

Sarmadi, M., Maru, N. and Kazemi, V. (2020) 'Association of COVID-19 global distribution and environmental and demographic factors An updated three-month study', Environmental Research, 188. doi: 10.1016/j.envres.2020.109748.

Setti, L., Passarini, F., De Gennaro, G., et al. (2020) 'SARS-Cov-2RNA Found On Particulate Matter Of Bergamo in Northern Italy: First evidence', Environmental Research, 188. doi: 10.1016/j.envres.2020.109754.

Setti, L., Passarini, F., de Gennaro, G., et al. (2020) 'The Potential Role Of Particulate Patter In The Spreading Of COVID-19 In Northern Italy: First Evidence-Based Research Hypotheses', medRxiv. doi: 10.1101/2020.04.11.20061713.

Son, J. Y., Fong, K. C., Heo, S., Kim, H., Lim, C.C., \& Bell, M. L. (2020) 'Reductions In Mortality Resulting From Reduced Air Pollution Levels Due To COVID-19 Mitigation Measures', Science of the Total Environment. Elsevier B.V., 20. doi: 10.1016/j.scitotenv.2020.141012.

Song, Y., Zhang, Y. and Dai, W. (2019) PM2.5 sources and their effects on human health in China: Case report. 2nd edn, Encyclopedia of Environmental Health. 2nd edn. Elsevier Inc. doi: 10.1016/B978-0-12-4095489.11664-1.

Stieb, D. M., Evans, G. J., To, T. M., Brook, J. R., and Burnett, R. T. (2020) 'An Ecological Analysis Of LongTerm Exposure To PM2.5 And Incidence Of COVID-19 In Canadian Health Regions', Environmental Research. Elsevier Inc., 191, p. 110052. doi: 10.1016/j.envres.2020.110052.

Urrutia-Pereira, M., Mello-da-Silva, C. A. and Solé, D. (2020) 'COVID-19 and air pollution: A dangerous 
association?', Allergologia et Immunopathologia. SEICAP, 48(5), pp. 496-499. doi: 10.1016/j.aller.2020.05.004.

Venter, Z. S. Aunan, K., Chowdhury, S., and Lelieveld, J. (2020) 'COVID-19 lockdowns Cause Global Air Pollution Declines With Implications For Public Health Risk', medRxiv, 7162. doi: 10.1101/2020.04.10.20060673.

World Health Organization (2020) 'Pesan dan Kegiatan Utama Pencegahan dan Pengendalian COVID-19 di Sekolah', in.

World Health Organization, W. (2021) WHO Coronavirus Disease (COVID-19) Dashboard, World Health Organization. Available at: https://covid19.who.int/ (Accessed: 23 February 2021).

World Health Organizationn (2021) Pertanyaan dan jawaban terkait Coronavirus, World Health Organization. Available at: https://www.who.int/indonesia/news/novel-coronavirus/qa/qa-for-public.

Wu, X. Nethery, R. C., Sabath, M. B., Braun, D., \& Dominici, F. (2020) 'Air Pollution And COVID-19 Mortality In The United States: Strengths And Limitations Of An Ecological Regression Analysis', Science Advances, 6(45), pp. 1-7. doi: 10.1126/SCIADV.ABD4049.

Yang, X., Yu, Y., Xu, J., Shu, H., Xia, J., Liu, H., Wu, Y., Zhang, L., Yu, Z., Fang, M., Yu, T., Wang, Y., Pan, S., Zou, X., Yuan, S., and Shang, Y. (2020) 'Clinical Course And Outcomes Of Critically Ill Patients With SARS-Cov-2 Pneumonia In Wuhan, China: A Single-Centered, Retrospective, Observational Study', The Lancet Respiratory Medicine. Elsevier Ltd, 8(5), pp. 475-481. doi: 10.1016/S22132600(20)30079-5.

Yao, Y., Pan, J., Wang, W., Liu, Z., Kan, H., Qiu, Y., Meng, X., \& Wang, W. (2020) 'Association Of Particulate Matter Pollution And Case Fatality Rate Of COVID-19 In 49 Chinese Cities', Science of the Total Environment. The Authors, 741. doi: 10.1016/j.scitotenv.2020.140396.

Zhou, P., Yang, X. L., Wang, X. G., Hu, B., Zhang, L., Zhang, W., Si, H. R., Zhu, Y., Li, B., Huang, C. L., Chen, H. D., Chen, J., Luo, Y., Guo, H., Jiang, R. D., Liu, M. Q., Chen, Y., Shen, X. R., Wang, X., Zheng, X. S., Zhao, K., Chen, Q. J., Deng, F., Liu, L. L., Yan, B., Zhan, F. X., Wang, Y. Y., Xiao, G. F., and Shi, Z. L. (2020) 'A pneumonia Outbreak Associated With A New Coronavirus Of Probable Bat Origin', Nature. Springer US, 579(7798), pp. 270-273. doi: 10.1038/s41586-020-2012-7.

Zoran, M. A., Savastru, R. S., Savastru, D. M., and Tautan, M. N. (2020) 'Assessing The Relationship Between Surface Levels Of PM2.5 And PM10 Particulate Matter Impact On COVID-19 In Milan, Italy’, Science of the Total Environment. National Institute of R\&D for Optoelectronics INOE 2000, 738, p. 139825. doi: 10.1016/j.scitotenv.2020.139825. 


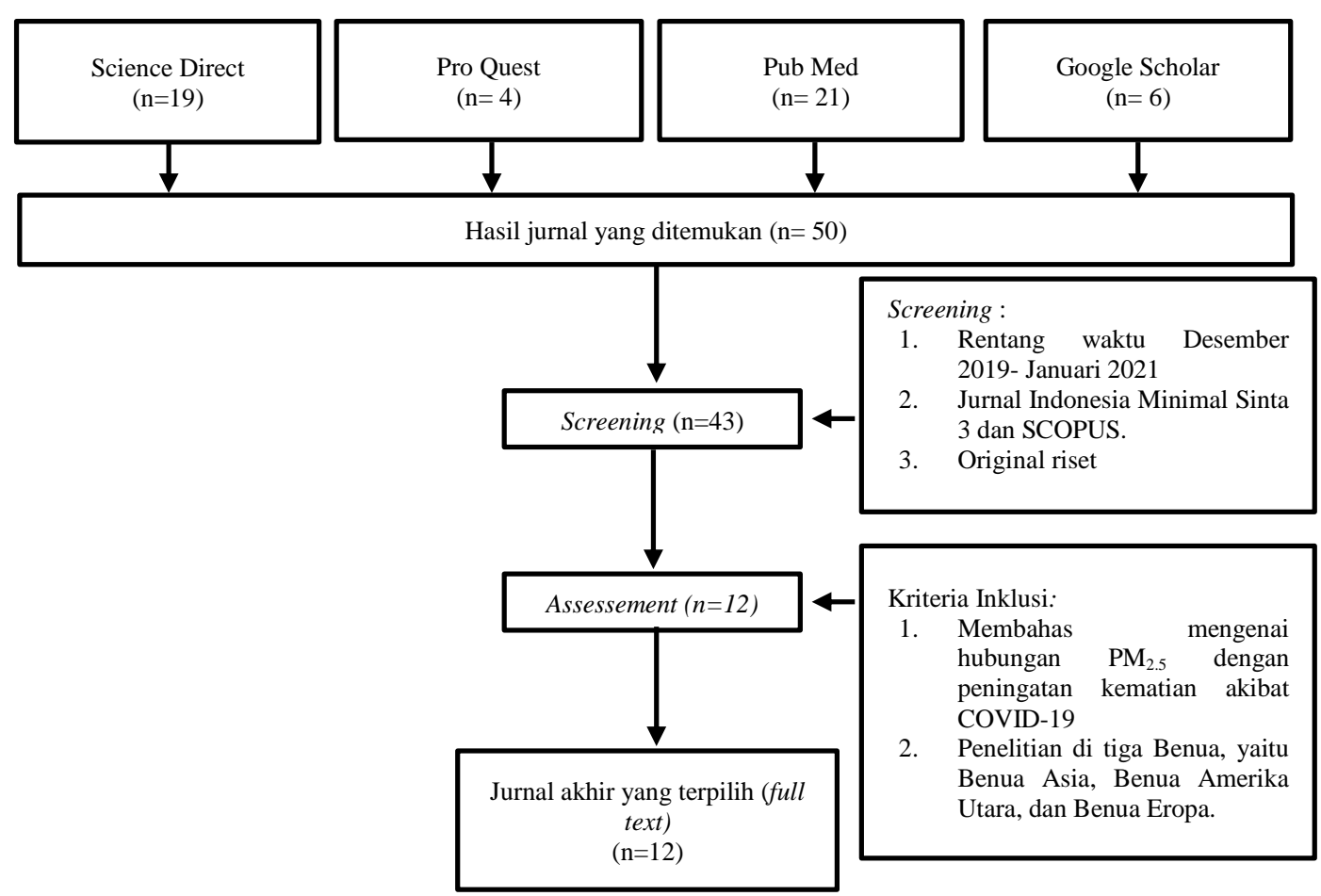

Gambar 1. Proses Seleksi Jurnal

Tabel 1. Artikel Review

\begin{tabular}{|c|c|c|c|c|c|c|c|}
\hline $\begin{array}{r}\mathbf{N} \\
\mathbf{0}\end{array}$ & $\begin{array}{c}\text { Nama } \\
\text { Pengarang }\end{array}$ & Judul & $\begin{array}{c}\text { Nama } \\
\text { Jurnal/ } \\
\text { Vol/ } \\
\text { Tahun }\end{array}$ & Tujuan & $\begin{array}{c}\text { Uji } \\
\text { analisis } \\
\text { data }\end{array}$ & Negara & Hasil \\
\hline 1 & $\begin{array}{l}\text { (Coker et al., } \\
\text { 2020) }\end{array}$ & $\begin{array}{l}\text { The Effects } \\
\text { of Air } \\
\text { Pollution on } \\
\text { COVID-19 } \\
\text { Related } \\
\text { Mortality in } \\
\text { Northern } \\
\text { Italy }\end{array}$ & $\begin{array}{l}\text { Environm } \\
\text { ental and } \\
\text { Resource } \\
\text { Economic } \\
s \\
\text { Volume } 7 \\
6 / \text { Issue 4/ } \\
\text { August } \\
2020\end{array}$ & $\begin{array}{l}\text { Untuk } \\
\text { mengetahui } \\
\text { hubungan } \\
\text { antara } \\
\text { konsentrasi } \\
\text { jangka } \\
\text { panjang PM } \\
\text { 2.5 dan } \\
\text { kematian } \\
\text { COVID-19 } \\
\text { di } \\
\text { Kotamadya } \\
\text { Itali Utara }\end{array}$ & $\begin{array}{l}\text { Mengguna } \\
\text { kan uji } \\
\text { regressi } \\
\text { linier }\end{array}$ & Italia & $\begin{array}{l}\text { Ada hubungan } \\
\text { signifikan } \\
\text { antara PM } 2.5 \\
\text { dengan } \\
\text { kematian } \\
\text { COVID-19 di } \\
\text { Kotamdaya } \\
\text { Utara Italia. } \\
\text { Dengan } \\
\text { kenaikan } \\
\text { konsentrasi } \\
\text { PM }{ }_{2.5} \text { sebesar } \\
1 \mu \text { g/m }{ }^{3} \text { maka } \\
\text { akan ada } \\
\text { kenaikan } \\
\text { kematian } \\
\text { akibat } \\
\text { COVID-19 } \\
\text { sebesar } 9 \%\end{array}$ \\
\hline
\end{tabular}




\begin{tabular}{|c|c|c|c|c|c|c|c|}
\hline 2 & $\begin{array}{l}\text { (Cole, Ozgen } \\
\text { and Strobl, 2020) }\end{array}$ & $\begin{array}{l}\text { Air Pollution } \\
\text { Exposure } \\
\text { and } \\
\text { Covid-19 in } \\
\text { Dutch } \\
\text { Municipaliti } \\
\text { es }\end{array}$ & $\begin{array}{l}\text { Environm } \\
\text { ental and } \\
\text { Resource } \\
\text { Economic } \\
\text { s } \\
\text { Volume } 7 \\
6 / \text { Issue 4/ } \\
\text { August } \\
2020\end{array}$ & $\begin{array}{l}\text { Untuk } \\
\text { mengetahui } \\
\text { hubungan } \\
\text { antara } \\
\text { paparan } \\
\text { jangka } \\
\text { panjang } \\
\text { polusi udara } \\
\text { dan COVID- } \\
19 \text { di } 355 \\
\text { kota di } \\
\text { Belanda }\end{array}$ & $\begin{array}{l}\text { Mengguna } \\
\text { kan uji } \\
\text { regresi non } \\
\text { linear }\end{array}$ & Belanda & $\begin{array}{l}\text { Kota di } \\
\text { Belanda yang } \\
\text { memiliki PM } \\
2.5 \text { dengan } \\
\text { konsentrasi } \\
1 \mu \mathrm{g} / \mathrm{m} 3 \text {, } \\
\text { memiliki } \\
\text { risiko 9,4\% } \\
\text { lebih banyak } \\
\text { kasus Covid- } \\
19, \text { memiliki } \\
\text { risiko 3\% } \\
\text { lebih banyak } \\
\text { masuk rumah } \\
\text { sakit, dan } \\
\text { memiliki } \\
\text { risikio 2,3\% } \\
\text { lebih banyak } \\
\text { terjadi } \\
\text { kematian } \\
\text { akibat } \\
\text { COVID-19 }\end{array}$ \\
\hline 3 & $\begin{array}{l}\text { (Fareed et al., } \\
\text { 2020) }\end{array}$ & $\begin{array}{l}\text { Co-variance } \\
\text { nexus } \\
\text { between } \\
\text { COVID-19 } \\
\text { mortality, } \\
\text { humidity, } \\
\text { and air } \\
\text { quality index } \\
\text { in Wuhan, } \\
\text { China: New } \\
\text { insights from } \\
\text { partial and } \\
\text { multiple } \\
\text { wavelet } \\
\text { coherence }\end{array}$ & $\begin{array}{l}\text { Air } \\
\text { Quality, } \\
\text { Atmosphe } \\
\text { re \& } \\
\text { Health } \\
\text { Volume } \\
\text { 13/ Issue } \\
\text { 6/ Juny } \\
2020\end{array}$ & $\begin{array}{l}\text { Untuk } \\
\text { dampak } \\
\text { iklim yang } \\
\text { dapat } \\
\text { menyebabka } \\
\text { n kematian } \\
\text { akibat } \\
\text { COVID-19 } \\
\text { di Wuha, } \\
\text { Ghina }\end{array}$ & $\begin{array}{l}\text { Mengguna } \\
\text { kan uji } \\
\text { wavelet }\end{array}$ & China & $\begin{array}{l}\text { Selama } \\
\text { periode } \\
\text { pengamatan } \\
\text { (21 Jan-31 } \\
\text { Maret 2020) } \\
\text { terjadi } \\
\text { peningkatan } \\
\text { kematian } \\
\text { akibat } \\
\text { COVID-19 } \\
\text { yang } \\
\text { dikarenakan } \\
\text { kualitas udara } \\
\text { yang buruk } \\
\left(\text { PM }_{2.5} \text {,) }\right.\end{array}$ \\
\hline 4 & $\begin{array}{l}\text { (Frontera et al., } \\
\text { 2020) }\end{array}$ & $\begin{array}{l}\text { Severe air } \\
\text { pollution } \\
\text { links to } \\
\text { higher } \\
\text { mortality in } \\
\text { COVID-19 } \\
\text { patients: The } \\
\text { "double hit" } \\
\text { hypothesis }\end{array}$ & $\begin{array}{l}\text { Journal of } \\
\text { Infection } \\
\text { Volume } \\
81 / \text { Issue } \\
2 / \text { Agust } \\
2020\end{array}$ & $\begin{array}{l}\text { Untuk } \\
\text { menganalisis } \\
\text { hubungan } \\
\text { antara } \\
\text { konsentrasi } \\
\text { pencemar } \\
\text { udara (PM } \\
\text { 2.5 dan } \mathrm{NO}_{2} \text { ) } \\
\text { dengan } \\
\text { wabah } \\
\text { COVID-19, } \\
\text { ditinjau dari } \\
\text { penularan, } \\
\text { jumlah } \\
\text { penderita, } \\
\text { keparahan, } \\
\text { dan jumlah } \\
\text { kematian }\end{array}$ & $\begin{array}{l}\text { Mengguna } \\
\text { kan uji } \\
\text { Korelasi } \\
\text { Perason }\end{array}$ & Italia & $\begin{array}{l}\mathrm{PM}_{2.5} \\
\text { berhubungan } \\
\text { secara } \\
\text { signifikan } \\
\text { dengan } \\
\text { kematian } \\
\text { COVID-19, } \\
\text { tetapi kuat } \\
\text { hubungannya } \\
\text { tidak terlalu } \\
\text { kuat dengan } \\
\text { nilai p = 0.032 } \\
\text { dan nilai r = } \\
0.53\end{array}$ \\
\hline
\end{tabular}




\begin{tabular}{|c|c|c|c|c|c|c|c|}
\hline 5 & $\begin{array}{l}\text { (Gupta et al., } \\
\text { 2020) }\end{array}$ & $\begin{array}{l}\text { Air pollution } \\
\text { aggravating } \\
\text { COVID-19 } \\
\text { lethality? } \\
\text { Exploration } \\
\text { in Asian } \\
\text { cities using } \\
\text { statistical } \\
\text { models }\end{array}$ & $\begin{array}{l}\text { Environm } \\
\text { en, } \\
\text { Developm } \\
\text { ent and } \\
\text { Sustainab } \\
\text { ility } \\
\text { Volume } \\
22 / \underline{\text { Issue }} \\
\underline{8 /} \\
\underline{\text { Desember }} \\
2020 \\
\end{array}$ & $\begin{array}{l}\text { Untuk } \\
\text { menganalisis } \\
\text { korelasi } \\
\text { antara polusi } \\
\text { udara di } \\
\text { suatu } \\
\text { wilayah dan } \\
\text { kematain } \\
\text { akibat } \\
\text { COVID-19 }\end{array}$ & $\begin{array}{l}\text { Mengguna } \\
\text { kan uji } \\
\text { regresi } \\
\text { liniear }\end{array}$ & $\begin{array}{l}\text { India, } \\
\text { Indonesi } \\
\text { a, } \\
\text { Pakistan, } \\
\text { dan } \\
\text { China }\end{array}$ & $\begin{array}{l}\mathrm{PM}_{2.5} \text { secara } \\
\text { signifikan } \\
\text { berkolerasi } \\
\text { dengan } \\
\text { kematian } \\
\text { COVID-19 (p } \\
<0.05) \text {. }\end{array}$ \\
\hline 6 & $\begin{array}{l}\text { (Hendryx and } \\
\text { Luo, 2020) }\end{array}$ & $\begin{array}{l}\text { COVID-19 } \\
\text { prevalence } \\
\text { and fatality } \\
\text { rates in } \\
\text { association } \\
\text { with air } \\
\text { pollution } \\
\text { emission } \\
\text { concentratio } \\
\text { ns and } \\
\text { emission } \\
\text { sources }\end{array}$ & $\begin{array}{l}\text { Environm } \\
\text { ental } \\
\text { Pollution } \\
\text { Volume } \\
265, \text { Part } \\
\text { A/Octobe } \\
\text { r } 2020\end{array}$ & $\begin{array}{l}\text { Untuk } \\
\text { mengetahui } \\
\text { hubungan } \\
\text { udara } \\
\text { terhadap } \\
\text { kematian } \\
\text { akibat } \\
\text { COVID-19 }\end{array}$ & $\begin{array}{l}\text { Mengggun } \\
\text { akan } \\
\text { regresi } \\
\text { linier } \\
\text { berganda }\end{array}$ & $\begin{array}{l}\text { Amerika } \\
\text { Serikat }\end{array}$ & $\begin{array}{l}\text { Semakin } \\
\text { tinggi tingkat } \\
\text { konsentrasi } \\
\mathrm{PM}_{2.5} \text { dan } \\
\text { materi } \\
\text { partikulat } \\
\text { diesel maka } \\
\text { tingkat } \\
\text { kematian } \\
\text { COVID-19 } \\
\text { juga tinggi }\end{array}$ \\
\hline 7 & $\begin{array}{l}\text { (Jiang and } \mathrm{Xu} \text {, } \\
\text { 2020) }\end{array}$ & $\begin{array}{l}\text { The } \\
\text { association } \\
\text { between } \\
\text { COVID-19 } \\
\text { deaths and } \\
\text { short-term } \\
\text { ambient } \\
\text { airpollution/ } \\
\text { meteorologic } \\
\text { al condition } \\
\text { exposure: a } \\
\text { retrospective } \\
\text { study from } \\
\text { Wuhan, } \\
\text { China }\end{array}$ & $\begin{array}{l}\text { Air } \\
\text { Quality, } \\
\text { Atmosphe } \\
\text { re \& } \\
\text { Health } \\
\text { Agust } \\
2020\end{array}$ & $\begin{array}{l}\text { Untuk } \\
\text { mengetahui } \\
\text { hubungan } \\
\text { antara } \\
\text { paparan } \\
\text { jangka } \\
\text { pendek } \\
\text { polusi udara } \\
\text { ambien/ } \\
\text { kondisi } \\
\text { metrology } \\
\text { terhadap } \\
\text { kematian } \\
\text { akibat } \\
\text { COVID-19 } \\
\text { di Wuhan }\end{array}$ & $\begin{array}{l}\text { Mengguna } \\
\text { kan uji } \\
\text { Person dan } \\
\text { Possion }\end{array}$ & China & $\begin{array}{l}\mathrm{PM}_{2.5} \\
\text { berpengaruh } \\
\text { terhadap } \\
\text { kematian } \\
\text { COVID-19 } \\
(\mathrm{RR}=1.079, \mathrm{p} \\
<0.01)\end{array}$ \\
\hline 8 & $\begin{array}{l}\text { (S. A. Meo et al., } \\
\text { 2020) }\end{array}$ & $\begin{array}{l}\text { Wildfire and } \\
\text { COVID-19 } \\
\text { pandemic: } \\
\text { effect of } \\
\text { environment } \\
\text { al pollution } \\
\text { PM- } 2.5 \text { and } \\
\text { carbon } \\
\text { monoxide on } \\
\text { the dynamics } \\
\text { of daily } \\
\text { cases and } \\
\text { deaths due } \\
\text { to SARS- } \\
\text { COV-2 } \\
\text { infection in } \\
\text { San } \\
\text { Francisco } \\
\text { USA }\end{array}$ & $\begin{array}{l}\text { European } \\
\text { Review } \\
\text { for } \\
\text { Medical } \\
\text { and } \\
\text { Pharmac } \\
\text { ological } \\
\text { Sciences } \\
\text { Volume } \\
24 / \text { Issue } \\
\text { 19/ } \\
\text { October } \\
2020\end{array}$ & $\begin{array}{l}\text { Untuk } \\
\text { mengetahui } \\
\text { hubungan } \\
\text { efek dari } \\
\text { polutan } \\
\text { kebakaran } \\
\text { hutan, yang } \\
\text { terdiri dari } \\
\text { partikulat } \\
\text { PM } 2.5 \text { dan } \\
\text { CO dalam } \\
\text { kasus harian } \\
\text { dan } \\
\text { kematian } \\
\text { akibat } \\
\text { COVID-19 } \\
\text { di San } \\
\text { Fransisco. } \\
\text { USA }\end{array}$ & $\begin{array}{l}\text { Mengguna } \\
\text { kan } \\
\text { Kolmogor } \\
\text { ov } \\
\text { Smirnov, } \\
\text { Korelasi } \\
\text { Perason, } \\
\text { dan } \\
\text { Regresi } \\
\text { non linier }\end{array}$ & $\begin{array}{l}\text { Amerika } \\
\text { Serikat }\end{array}$ & $\begin{array}{l}\text { Ada hubungan } \\
\text { signifkan } \\
\text { antara } \mathrm{PM}_{2.5} \\
\text { dengan } \\
\text { kematian } \\
\text { kumulatif } \\
\text { akibat } \\
\text { COVID-19 } \\
(\mathrm{r}=0.567 \text {, } \\
\text { p<0.001). } \\
\text { Namun PM } 2.5 \\
\text { tidak } \\
\text { berpengaruh } \\
\text { terhadap } \\
\text { kematian } \\
\text { harian akibat } \\
\text { COVID-19 }\end{array}$ \\
\hline
\end{tabular}




\begin{tabular}{|c|c|c|c|c|c|c|c|}
\hline 9 & (Son et al., 2020) & $\begin{array}{l}\text { Reductions } \\
\text { inmortality } \\
\text { resulting } \\
\text { fromreduced } \\
\text { air pollution } \\
\text { levels due to } \\
\text { COVID-19 } \\
\text { mitigation } \\
\text { measures }\end{array}$ & $\begin{array}{l}\text { Science of } \\
\text { the Total } \\
\text { Environm } \\
\text { ent } \\
\text { Volume } \\
20 / \\
\text { November } \\
2020\end{array}$ & $\begin{array}{l}\text { Untuk } \\
\text { mengetahui } \\
\text { dampak } \\
\text { tindakan } \\
\text { mitgasi } \\
\text { pengurangan } \\
\text { polusi udara } \\
\text { terhadap } \\
\text { kematian } \\
\text { akibat } \\
\text { COVID-19 } \\
\text { di } 10 \text { negara } \\
\text { bagian } \\
\text { Amerika } \\
\text { Distric } \\
\text { Kolombia }\end{array}$ & $\begin{array}{l}\text { Mengguna } \\
\text { kan uji } \\
\text { regresi } \\
\text { linier }\end{array}$ & $\begin{array}{l}\text { Amerika } \\
\text { Serikat }\end{array}$ & $\begin{array}{l}\text { Penurunan } \\
\text { tingkat } \\
\text { kematian } \\
\text { akibat } \\
\text { COVID-19 di } \\
\text { California } \\
\text { terjadi karena } \\
\text { adanya } \\
\text { mitigasi } \\
\text { penurunan } \\
\text { polusi udara, } \\
\text { khsuusnya PM } \\
\text { 2,5. Rata-rata } \\
\text { penurunan } \\
\text { konsentrasi } \\
\text { PM } 2.5 \text { sebesar } \\
\text { 12.8\% }\end{array}$ \\
\hline 10 & $\begin{array}{l}\text { (Sultan Ayoub } \\
\text { Meo et al., 2020) }\end{array}$ & $\begin{array}{l}\text { Effect of } \\
\text { Environment } \\
\text { al Pollutants } \\
\text { PM-2.5, } \\
\text { Carbon } \\
\text { Monoxide, an } \\
\text { d Ozone on } \\
\text { the } \\
\text { Incidence } \\
\text { and } \\
\text { Mortality of } \\
\text { SARS-COV- } \\
2 \text { Infection } \\
\text { in Wildfire } \\
\text { Affected Ten } \\
\text { Counties in } \\
\text { California }\end{array}$ & $\begin{array}{l}\text { Science of } \\
\text { the Total } \\
\text { Environm } \\
\text { ent } \\
\text { Volume } \\
757, \\
\text { February } \\
2021\end{array}$ & $\begin{array}{l}\text { Untuk } \\
\text { mengetahui } \\
\text { hubungan } \\
\text { efek dari } \\
\text { polutan } \\
\text { kebakaran } \\
\text { hutan, yang } \\
\text { terdiri dari } \\
\text { partikulat } \\
\mathrm{PM}_{2.5}, \mathrm{O}_{3} \text {, } \\
\text { dan CO } \\
\text { dalam kasus } \\
\text { harian dan } \\
\text { kematian } \\
\text { akibat } \\
\text { COVID-19 }\end{array}$ & $\begin{array}{l}\text { Mengguna } \\
\text { kan uji t- } \\
\text { Welch dan } \\
\text { uji } \\
\text { Regressi } \\
\text { non linier }\end{array}$ & $\begin{array}{l}\text { Amerika } \\
\text { Serikat }\end{array}$ & $\begin{array}{l}\mathrm{PM}_{2.5} \\
\text { berhubungan } \\
\text { secara } \\
\text { signifikan } \\
\text { dengan } \\
\text { kematian } \\
\text { COVID-19, } \\
\text { namun } \\
\text { hubungannya } \\
\text { lemah (p } \\
<0.001, \mathrm{r}= \\
0.171)\end{array}$ \\
\hline 11 & (Wu et al., 2020) & $\begin{array}{l}\text { Air pollution } \\
\text { and COVID- } \\
19 \text { mortality } \\
\text { in the United } \\
\text { States: } \\
\text { Strengths } \\
\text { and } \\
\text { limitations of } \\
\text { an } \\
\text { ecological } \\
\text { regression } \\
\text { analysis }\end{array}$ & $\begin{array}{l}\text { Science } \\
\text { Advances } \\
\text { Volume 6/ } \\
\text { Issue 45/ } \\
\text { November } \\
2020\end{array}$ & $\begin{array}{l}\text { Untuk } \\
\text { mengetahui } \\
\text { paparan } \\
\text { jagka } \\
\text { panjang } \\
\text { polusi udara } \\
\text { dengan } \\
\text { kematian } \\
\text { akibat } \\
\text { COVID-19 } \\
\text { di Amerika } \\
\text { Serikat }\end{array}$ & $\begin{array}{l}\text { Mengguun } \\
\text { akan uji } \\
\text { regresi } \\
\text { linier }\end{array}$ & $\begin{array}{l}\text { Amerika } \\
\text { Serikat }\end{array}$ & $\begin{array}{l}\text { Ada hubungan } \\
\text { signifikan } \\
\text { antara PM } 2.5 \\
\text { dengan } \\
\text { kematian } \\
\text { COVID-19 di } \\
\text { Amerika } \\
\text { dengan p = } \\
0.00 \text {, setiap } \\
\text { peningkatan } \\
\text { PM } 2.5 \\
\text { sebesar } 1 \\
\mu \text { g/m }{ }^{3} \text { dapat } \\
\text { meningkatkan } \\
11 \% \text { kematian } \\
\text { akibat } \\
\text { COVID-19 di } \\
\text { Amerika } \\
\text { Serikat }\end{array}$ \\
\hline 12 & $\begin{array}{l}\text { (Yao et al., } \\
2020)\end{array}$ & $\begin{array}{l}\text { Association } \\
\text { of } \\
\text { particulate } \\
\text { matter } \\
\text { pollution } \\
\text { and case } \\
\text { fatality rate }\end{array}$ & $\begin{array}{l}\text { Science of } \\
\text { the Total } \\
\text { Environm } \\
\text { ent } \\
\text { Volume } \\
741 / \\
\text { November }\end{array}$ & $\begin{array}{l}\text { Untuk } \\
\text { mengetahui } \\
\text { hubungan } \\
\text { materi } \\
\text { partikulat } \\
\text { (PM) dengan } \\
\text { Case fatality }\end{array}$ & $\begin{array}{l}\text { mengguna } \\
\text { kan uji } \\
\text { regresi } \\
\text { liniear }\end{array}$ & China & $\begin{array}{l}\text { Ada hubungan } \\
\text { antara PM } \\
\text { dengan CFR } \\
\text { COVID-19 di } \\
\text { kota-kota baik } \\
\text { di dalam } \\
\text { maupun di }\end{array}$ \\
\hline
\end{tabular}


319 Media Gizi Kesmas, Vol. 10, No 02 Desember 2021: Halaman : 307-319

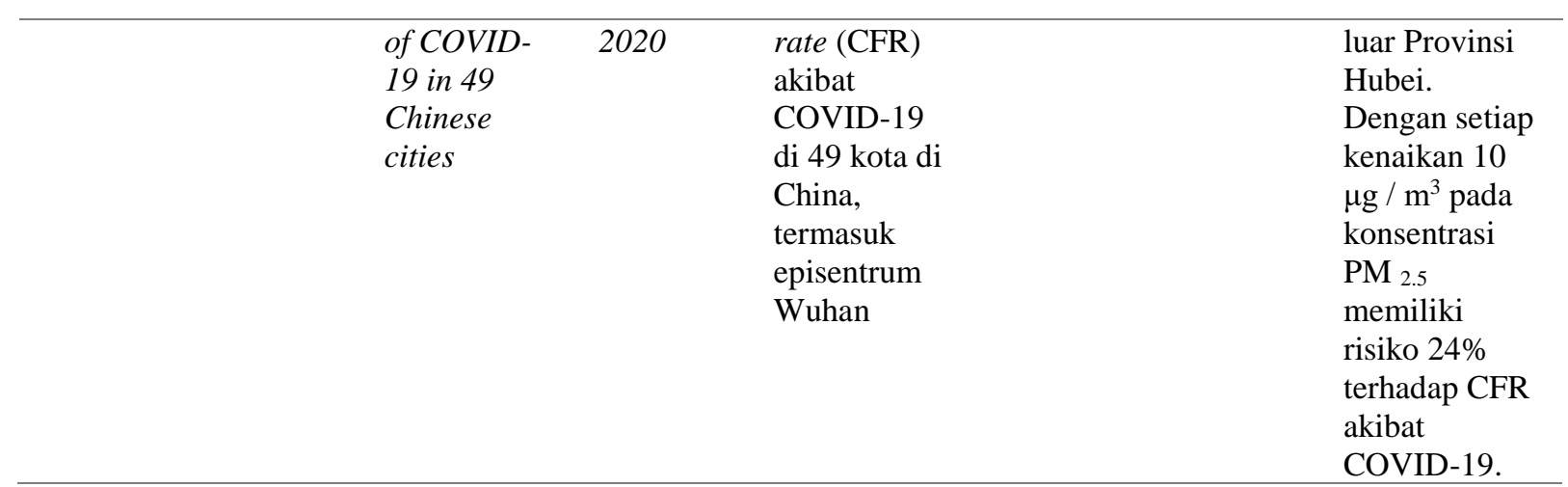

